\title{
\begin{tabular}{l|l|l|} 
University of & FOUNDED \\
St Andrews & 1413
\end{tabular}
}

University

Library

\section{Philosophy and liturgy part 1: liturgy and philosophy of action}

Joshua Cockayne

\begin{tabular}{|c|c|}
\hline Date of deposit & 10082018 \\
\hline Document version & Author's accepted manuscript \\
\hline Access rights & $\begin{array}{l}\text { (C) } 2018 \text { The Author(s) Philosophy Compass (c) } 2018 \text { John Wiley \& } \\
\text { Sons Ltd. This work is made available online in accordance with } \\
\text { the publisher's policies. This is the author created, accepted } \\
\text { version manuscript following peer review and may differ slightly } \\
\text { from the final published version. }\end{array}$ \\
\hline $\begin{array}{l}\text { Citation for } \\
\text { published version }\end{array}$ & $\begin{array}{l}\text { Cockayne, J. (2018). Philosophy and liturgy part 1: liturgy and } \\
\text { philosophy of action. Philosophy Compass, Early View, [e12547]. }\end{array}$ \\
\hline $\begin{array}{l}\text { Link to published } \\
\text { version }\end{array}$ & https://doi.org/10.1111/phc3.12547 \\
\hline
\end{tabular}

Full metadata for this item is available in St Andrews Research

Repository at: https://research-repository.st-andrews.ac.uk/

\section{St Andrews Research Repository}




\title{
Philosophy and Liturgy Part 1 Liturgy and the Philosophy of Action
}

\begin{abstract}
In this article, I summarise recent philosophical work on the philosophy of liturgy. In part 1 of this article, I consider how liturgy can provide a way of acting. I outline the importance of a liturgical script for enacting a liturgy, as well discussing the role of the body in acting liturgically. I conclude by considering the corporate dimension of liturgical action.
\end{abstract}

Keywords: Liturgy, philosophy of action, scripted action, embodiment, collective-intention, joint-agency.

\section{A Liturgical Turn in the Philosophy of Religion}

For the most part, philosophy of religion in the past century has concerned itself with clarifying and evaluating religious beliefs. ${ }^{1}$ Yet, as some philosophers have pointed out, there is a disparity between what occupies the minds of religious believers and what philosophers of religion focus on. As Mark Wynn describes this disparity, there appears to be a different set of questions 'on the street' than those that philosophers occupy themselves with answering $(2012,12)$. These questions, as Wynn goes on to describe them, are concerned not with apologetic concerns, but, rather, with a certain way of life $(2012,12)$. A key component of the religious way of life which philosophers have often ignored, as Kevin Schilbrack points out, is that of certain ritual practices $(2014,17)$.

Nicholas Wolterstorff, one of the leading thinkers in the philosophical study of liturgy, echoes this concern in the conclusion of his 1990 essay on liturgy. He writes,

Christian existence incorporates Christian belief and Christian ethical action, Christian experience and Christian ritual. In our century we who are Christian philosophers have thought especially about Christian belief and Christian ethics, somewhat about Christian experience. We have thought scarcely at all about Christian liturgy.... Someone might reply...that it shows...that there is little of interest for philosophers in liturgy. If I have done nothing else in this essay, I hope I have made you suspect, if not actually believe, that this is false. It would be a pity if philosophers had nothing to say about this fundamental dimension of Christian existence. $(1990,157)$.

Whilst the progress Wolterstorff envisaged might have been slower than anticipated, nearly 30 years after these words were published, the philosophical landscape is starting to show signs of taking these concerns seriously. As James K.A. Smith describes it, there has been something of a 'liturgical turn' $(2018,118)$ in philosophy of religion in both the analytic and continental traditions. ${ }^{2}$ Philosophers have begun to take note of the philosophical issues which arise from a focus away from religious beliefs and onto certain practices, more specifically, the practices involved in the liturgy of the Church. In this article, I outline some of these recent philosophical discussions of liturgical practice and consider how this discussion might develop in the future.

\footnotetext{
${ }^{1}$ Two notable exceptions, perhaps, are the much-discussed problem of petitionary prayer and the nature of religious experience. Other than this, a cursory glance at the contents pages of recent collections in philosophy of religion or analytic theology will reveal a focus primarily on the question of whether belief in God is rationally defensible and whether Christian doctrine is logically coherent.

${ }^{2}$ In this article, I primarily cover analytic work on liturgy. Whilst I do consider some work which is broadly in the continental tradition (Smith 2009, 2013, 2017; Benson 2013), I omit other recent continental discussions for sake of brevity and clarity. For other recent discussions of liturgy in continental philosophy, see Christina M. Gschwandtner (2015; 2013,163-183) and John D. Caputo (2007).
} 


\section{Defining Liturgy}

First, we should note the complexity of the term 'liturgy' as it is used in the philosophical literature. 'Liturgy' has been used broadly to denote all goal orientated practices or rituals in human life, but also much more specifically, to refer only to certain practices of the gathered Church.

In the broad sense of the word, Bruce Ellis Benson, writes that, 'although "liturgy" is used almost exclusively today in connection with church services, it original referred to how people lived...Liturgy was never intended to be something merely done on a Sunday. Instead, liturgy is a way of live' $(2013,24)$. Similarly, Smith, who has written extensively on the philosophy of liturgy, writes of human persons as homo liturgicus, that is, as creatures who are shaped by certain rituals and practices which determine the kind of things they love, and, thus, the kind of people they are. For Smith, this is at the heart of the nature of liturgies, which are, as he defines it, 'rituals of ultimate concern: rituals that are formative for identity, that inculcate particular visions of the good life, and do so in a way that means to trump other ritual formations' $(2009,86)$. As Smith describes it, liturgy is pervasive in all aspects of human life, and not restricted merely to the practices of the Church.

Yet, there is also a much narrower sense of 'liturgy' which is more often discussed by philosophers. As Benson notes (borrowing from Charles P. Price and Louis Weill (1979)), we can make a distinction between 'intensive liturgy', that is, the worship of a gathered group of religious believers, and 'extensive liturgy', that is, how these religious believers act in their daily lives after gathered worship disperses $(2012,128)$. As Benson is keen to stress, these two kinds of liturgy cannot be disconnected-liturgical worship does not stop when one leaves a place of worship. However, this narrower intensive use of liturgy is much closer to how the word is used in much of the analytic work on the subject. As Wolterstorff observes, whilst the word 'liturgy' is used more broadly to refer to extensive liturgies, the focus of his own work is that of the scripted worship of a Christian community $(2018,11-12)$. As he goes on to define it,

An enactment of a liturgy consists of the participants together performing scripted verbal, gestural and auditory actions, the prescribed purpose of their doing so being both to engage God directly in acts of learning and acknowledging the excellence of who God is and what God has done, and to be engaged by God. And the liturgy itself is that type of sequence of act-types that is enacted when the participants do what the script prescribes. $(2018,29-3)$

In this article, I focus primarily on philosophical approaches to intensive liturgy, of the kind described here by Wolterstorff. There appears to be little disagreement as to how to define 'intensive liturgy', and Wolterstorff's definition seems broadly compatible with many of the other accounts discussed. It's important to note, from the beginning, that liturgy is not something practiced only in formal or traditional Churches. As Wolterstorff observes, even worship with no written script or liturgical text should be considered 'liturgical', since there is always a script involved in worship, even if this is implicit $(2015,9)$. There are right and wrong ways of worshipping in such contexts, and cultural expectations of how one should act, even if these are as minimal as standing up to sing a hymn, or not heckling when the preacher is speaking.

In this two-part article, I outline two areas of philosophical study within this growing literature: the nature of liturgical action and the epistemology of liturgy. For, whilst the literature on philosophy and liturgy is relatively small, it's also remarkably broad in subject matter. There has been work on the intersection between liturgy and the philosophy of desire and emotion, ${ }^{3}$

\footnotetext{
${ }^{3}$ Smith, 2009; Cuneo 2016, 20-37.
} 
ethics, ${ }^{4}$ political philosophy, ${ }^{5}$ philosophy of language, ${ }^{6}$ as well as the problem of divine hiddenness. ${ }^{7}$ However, the questions 'What are we doing when we participate in liturgy?' and 'What can we know by participating in liturgy?' appear to have been recurring questions in much of this literature, and so these are the two questions I will consider. In the first part of this article, I consider the relationship between liturgy and philosophy of action, and in the second part article, I consider recent work on the epistemology of liturgy.

\section{Acting Liturgically}

What are we doing when we engage in liturgy? This has been a question which has been addressed by many of those writing on the philosophy of liturgy. As Terence Cuneo observes, 'to the untrained eye' the liturgies of his own tradition, the Eastern Orthodox Church, appear to be a 'jumble of disconnected actions' $(2016,154)$, such as 'kissing, standing, bowing, prostrating, chanting, singing, anointing, processing, praying, kneeling, sensing, reading, listening, eating, washing, vesting....and even spitting' (2016, 154). With 'increased exposure', Cuneo suggests, one would come to see that such actions aren't random, disconnected events, but, rather, scripted actions which form the part of a central pattern of engaging God by blessing, petitioning and offering thanks to God $(2016,156)$.

Wolterstorff agrees that liturgy primarily has to do with engaging God in important ways. He suggests that, '[l]iturgy is a species of ritual' which 'has to do with God. More specifically, when enacting a liturgy the participants orient themselves toward God... When we orient ourselves toward God by enacting a liturgy we engage God directly and explicitly' $(2018,27)$. Moreover, whilst we might use the term 'liturgy' to refer to a text used in communal worship, Wolterstorff claims that 'a liturgical text exists not for its own sake but for the sake of enactments of the liturgy' $(2015,4)$. As Wolterstorff defines it, liturgy is a 'universal', that is, something which 'can be repeatedly enacted' $(2015,4)$. More specifically, liturgies are 'types of sequences of actions of certain kinds' that always include bodily actions (such as 'listening, speaking, singing...crossing oneself, distributing bread and wine... and more besides' $(2015,5)$ ) as well as non-bodily actions such as blessing and thanking. In the context of liturgy, bodily actions 'count as performances of actions that are not bodily' (2015, 5). As Cuneo expands this point, bodily acts 'do not merely accompany the linguistic acts prescribed by the liturgical script' but, rather, in the context of liturgy, these bodily actions 'count as cases of engaging God by blessing, petitioning and thanking God' (2016, 156).

According to Cuneo, successfully thanking God in the liturgy doesn't depend on having a specific mental state: 'to thank someone at some time, one needn't be feeling gratitude at that time' $(2016,157)$, but requires only that the relevant intention is present. If the agent wants to thank God by repeating the words of the liturgical script 'thanks be to God', whilst she doesn't need to feel gratitude, she does need to intend that this speech-act count as an instance of thanking God. Wolterstorff makes a similar point in his discussion of whether having faith in God is required for successfully performing liturgical actions. Wolterstorff suggests that in the instance of someone who utters, 'Thanks be to God', 'on the off-chance and in the hope that God does exist and is the sort of being who can be thanked and who is worthy of being thanked' $(2018,104)$; if such a God does exist, then this person has thanked God. Wolterstorff even goes as far as suggesting that ' $[\mathrm{i}] \mathrm{f}$ it is the intention of the participant, when performing the prescribed verbal and gestural acts, that he not thereby perform the prescribed acts of worship, then he has not performed them; otherwise he has' $(2018,108)$.

Whilst, for Cuneo and Wolterstorff, the success conditions of acting liturgically don't depend on the agent's mental states or beliefs, but only their intentions (or absence of negative

\footnotetext{
${ }^{4}$ Wolterstorff, 2011, 2018: 249-273; Cuneo, 2016: 88-106, 37-52.

${ }^{5}$ Smith, 2017.

${ }^{6}$ Wolterstorff, 1995, 2015.

${ }^{7}$ Cuneo, 2016: 52-66.
} 
intentions), liturgical acts can be evaluated in terms of how appropriately they engage God. For instance, in the case of the person who thanks God without having faith in God, Wolterstorff thinks such a person thanks God, but writes that this 'is not a well-formed instance of thanking God' $(2018,104)$. Cuneo suggests that the liturgical script provides us with the opportunity not only to engage God simpliciter, but also to engage God appropriately. Just as in ordinary social situations there are apt and inapt ways of expressing thanks (writing a letter as a means of expressing thanks for passing the salt appears to be an inapt way of expressing thanks, for instance $(2016,164)$ ), Cuneo suggests that 'the liturgical script... repeatedly draws attention to the fact that the ways of acting it prescribes are not inapt' $(2016,164)$.

Smith also describes himself as developing an account of 'Christian action' $(2013,4)$ in reference to both intensive and extensive liturgies. He writes that 'worship is best understood on the order of action not reflection; worship is something we do' $(2009,166)$. Smith's philosophy of liturgical action is rooted in his account of anthropology. Rejecting an account of human beings as primarily rational beings, Smith depicts human beings as desiring, ritualistic, embodied creatures. All of our liturgical action (whether that be through the rituals of the intensive liturgy of a Church tradition, or the rituals which undergird how think, eat, shop and relate to each other) should be seen as intentional actions, $(2009,48)$, even if this intentionality exists only at a pre-reflective and non-cognitive level (2009, 50-51). Indeed, Smith thinks, this kind of noncognitive mode is our 'default way of intending the world' (2009, 50-51). Smith's account of liturgical action is explained in terms of desire: 'What distinguishes us' as human beings, he writes, 'is not whether we love, but what we love' $(2009,52)$. Thus, for Smith, acting liturgically is guided by our desires, rather than our rational decision-making.

Smith's account of acting liturgically then informs his account of what it is to engage in the liturgies of Christian worship. As he describes it, the role of Christian liturgies is to help the worshipper cultivate habits which can orientate their action towards God's goodness in a way that becomes second-nature to them. 'The practices of Christian worship', Smith writes, provide 'an understanding of our environment that is precognitive and becomes inscribed in our adaptive unconscious' $(2009,68)$. For Smith, one of the important roles of Christian worship is to 'form — or better, reform - our habits and dispositions' $(2013,166)$ from those entrenched in us by culture which run counter to God's purposes for us. It does this, he claims, not by 'providing new knowledge' of the points of difference between culture and Christianity, but, rather, he writes, by providing a kind of "dispositional deflection" and rehabitulation of our desires and loves' $(2013,166)$. Given the importance of habitualation (and rehabitulation) of our desires in Smith's account of liturgy, Smith puts an important emphasis on repetition-he suggests that '[i]f Christian worship is going to be formative, it has to be repetitive' $(2013,185) .^{8}$ This emphasis on liturgy's repetitiveness points to another important feature of acting liturgicallythe need for a liturgical script.

\section{Scripted liturgical action}

As Wolterstorff describes it, 'Those who participate in enacting some liturgy do so by following what I shall call a script, the result being scripted activity' $(2018,13)$. In a number of places, Wolterstorff makes comparisons between the ontology of liturgy and the ontology of music to explain the relation between a script and the performance of some act-type $(2015,5)$. In the performance of some orchestral symphony, for instance, a musician follows a score to guide her to perform a certain sequence of sounds, and, he argues, 'the musical work is the sound sequence type that is instantiated when the correctness-rules that the composer has instantiated are faithfully followed' $(2015,6)$. Similarly, the liturgical script of a particular tradition 'specifies a set of rules for a correct liturgical enactment' $(2015,7)$, which, in turn allows for the performance of certain acts of worship. Wolterstorff notes that scripts can be followed 'correctly

${ }^{8}$ Wolterstorff considers the importance of repetition in liturgical scripts in Acting Liturgically $(2018,148-170)$. 
or incorrectly' $(2018,15)$, even if these correctness rules are often 'tradition-specific' $(2015,8)$. Thus, just as a team of American football players can execute their game plan correctly or incorrectly, a congregation can follow a liturgical script correctly or incorrectly. To follow a liturgical script correctly, requires suspending acting on one's own judgement 'as to what would be good to do and instead follow the script' $(2018,15)$. This requires a kind of submission to the authorities of one's tradition, Wolterstorff thinks - 'to be inducted into the tradition of Catholic liturgical practice is to be confronted with the authority of that tradition' $(2018,51)$.

Yet, whilst a tradition determines the actions one is to perform in engaging God, a script cannot prescribe all the actions that should be performed $(2018,16)$ — 'the script for enacting a particular liturgy is never fully specified by a text, nor by a text supplemented by oral directives. Always some of the prescriptions constituting the script are embedded within the social practice of that particular religious community for enacting its liturgies' $(2018,20)$. As Smith describes, there is a kind of irreducible logic of practice which can only be acquired by being embedded in a liturgical community $(2013,77)$. Thus, whilst liturgical scripts prescribe some of the actions involved in engaging God liturgically, some of our liturgical behaviour must be learned through experience.

This importance of performing actions which aren't prescribed by the liturgical script, but which are part of acting liturgically is developed in more detail by Benson. Like Wolterstorff, Benson makes comparisons between music and liturgy, but instead of making the comparison with an orchestral score, Benson thinks of liturgy as a kind of improvised jazz $(2013,9)$. He writes that, 'in jazz, knowing the past is what makes the future possible. In the same way, learning to be a Christian improviser, one must know the entire context: Scripture and the ways in which Scripture has been interpreted in the past. In short, one must be part of a community of improvisers' (2013, 42). As Benson notes, jazz is not without a script or certain rules of correctness-but, rather, our improvisations must take place against the backdrop of this script. Thus, he claims that, "[n]ot only are many "improvisations" often significantly "scripted," but spontaneity is only possible when one is well prepared...It takes a great deal of work to be spontaneous' $(2012,41)$. The same is true in the use of Christian liturgy; Benson describes the ideal of Christian liturgical action as a kind of scripted spontaneity $(2013,140)$ which is made possible by closely following a script but being prepared to adapt and modify one's performance of the script. Whilst liturgy is always scripted and repetitive, Benson states that, 'there is still a difference between one repetition and another, in the same way that there is a difference between one performance of a symphony and another' $(2013,141){ }^{9}$

\section{Bodily liturgical action}

As I've already described, many of the liturgical actions involved in following a liturgical script involve agents performing bodily actions. On Wolterstorff's and Cuneo's accounts, in the context of Christian worship, these bodily actions count as instances of engaging God by thanking, blessing and petitioning God. Another important aspect of acting liturgically is that these actions are bodily. In his most recent work, Wolterstorff expands this account in more detail. Here he suggests that there is a kind of joining of body and mind in the acts of liturgical worship. It's not the case, he suggests, that uttering words of thanks causes my thanking God, but, rather, 'I perform that act by using my tongue and vocal chords to utter the words "Thanks be to God." ... My uttering of the words counts as my thanking God. My act of uttering the words and my act of thanking God are joined together so that the former counts as the latter' $(2018,85)$. As Wolterstorff suggests, bodily actions are integral to liturgy. Without our bodies, 'there would be no declaration of pardon and no blessing of the people...there would be no singing... [and] there

\footnotetext{
${ }^{9}$ As Smith suggests, the fact that following a liturgy depends on being embedded in a liturgical community, means that theorizing about liturgy will never get at the irreducible 'logic of practice' $(2013,77)$, pointing to one of the limits of philosophical thinking about liturgy. He writes that, 'any adequate interpretation of what's going on in such a community of practice will need to resist the temptation to construe practitioners as implicit theorizers' $(2013,77)$.
} 
would be no sacraments' $(2018,90)$, and thus, we wouldn't have access to the goods these things make possible. ${ }^{10}$

Smith's account of acting liturgically gives an important role to bodily action, perhaps more so than any other account. As I've already described, Smith thinks of liturgy as a kind of habitual outworking of our desires. It's essential to this account, to realise that we exist as embodied creatures in the world: 'We are in the world primarily as doers, not thinkers-and ever our thinking serves, and grows out of our doing. We are certainly more than our bodies, but we are never less than that' $(2012,113)$. Indeed, one of the crucial ways in which Christian liturgies can counter the liturgies of culture is through bodily action. He writes that

gestures are not just something we do but...they also do something to us... kneeling for confession is a kind of cosmological act that inscribes in us a comportment to God and neighbour, a way of being-in-the-world that inks into our bones and becomes sedimented into the core our being through the crackle of our old knees. The postures of our bodies spill out beyond the sanctuary and become postures of existential comportment to the world. $(2013,167)$

Finally, as Wolterstorff suggests, one of the crucial values of the bodily dimension of acting liturgically is that it allows us to worship communally $(2018,90)$. He argues that, without our bodies, 'the communal dimension of liturgical enactments... would be entirely missing' (2018, 90). It is to this aspect of liturgy which I now turn.

\section{Communal liturgical action}

As many in the literature have pointed out, the intensive liturgy of the Church is not performed by individuals but by communities and congregations. Wolterstorff writes, "The church blesses God, praises God, thanks God, confess her sins to God, petitions God, listens to God's Word, celebrates the Eucharist. It's not the individual members who do these things simultaneously; it's the assembled body that does these things' $(2015,11)$. Similarly, Smith argues that 'worship is not a private affair; we have gathered as a people, as a congregation, and just as together we are dependent on our redeeming Creator, so too are we dependent on one another. All the parts of the body are dependent upon other parts and organs in order for the individual parts ("me") to function and flourish' $(2009,169)$. Thus, giving an account of the importance of acting communally is important for giving an account of acting liturgically.

Both Cuneo and Wolterstorff have attempted to apply work in the philosophy of collective intention to explain the corporate aspect of communal worship. Cuneo draws on work by John Searle (1990, 2010) and Wolterstorff, Michael Bratman (2009). In Cuneo's discussion of liturgical singing, for instance, there is a kind of interlocking of individual intentions and a responsiveness to others which means that it is the congregation and not the individuals who should be regarded as the agents of liturgical singing. To explain how this might be so, Cuneo suggests that Searle's model of collective intention can give such an account. Thus, on Searle's account, when cooperation is present in this way, the structure of our intentions is different. To take an example which Searle uses, that of the piano/violin duet (2010, 52), it's not that I intend that I play the piano whilst believing that you play the violin. That is, for Searle, acting together isn't a case of us both individually intending to act at the same time. But, rather, as he describes it,

\footnotetext{
${ }^{10}$ Cuneo (2017) also considers the religious worth of bodily liturgical actions in a recent article which is not included in his Ritualized Faith collection. He writes that bodily liturgical actions 'have religious worth, in part, because their performance is expressive of the religious attitudes, which themselves have religious worth. More importantly, the worth of these actions is not wholly determined by the attitudes that agents are in... when performing these actions but also the attitudes that God has to their performance' $(2017,18)$.
} 
$[w]$ are performing a duet where I play the piano part and you play the violin part. Here our playing does not cause the duet to be performed. My playing and your playing simply constitute the performance of the duet. So from my point of view, I have a collective intention-in-action that we ply the duet by way of me playing the piano, in a context where $I$ take it for granted that you are playing the violin. (2010, 52; emphasis in the original)

In Searle's example, my intention is a collective intention (or a 'we-intention') rather than an individual intention. Searle thinks that it's not the case that I merely intend to play the piano and I believe that you will play the violin, as he thinks some accounts of collective intention describe; rather, the content of my intention is different when I act cooperatively than when I act individually-I intend to act collectively. Now, whilst Searle thinks that I must have certain beliefs about what the other will do, these beliefs aren't what make my intention collective; instead, there is something irreducible about the nature of my intention when I act cooperatively. In harmony with Searle's thought, Cuneo writes,

Group singing clearly seems to satisfy the criteria for collective action specified above: it requires the requisite "we intentions," that these intentions fit together in the right ways, and awareness of one another's intentions... to engage in group singing also requires that I adjust my singing to yours and that you adjust your singing to mine in "real time," often in ways that are not dictated by the score that we are following. $(2016,138)$

For Searle, the 'we-intentions' described above are an irreducible phenomenon of group action which resist further analysis. For this reason, Wolterstorff prefers to analyse group liturgical actions using Bratman's (2009) analysis in which we-intentions are individual intentions which mesh, or interlock, in some way. Wolterstorff suggests that, 'when the participants in some liturgical enactment come together they don't do any such thing as come to agreement with each other over their actions. Joint action automatically results from each participant intending to fill his or her role in together following the script. Shared joint-action intentions that interlock emerge automatically' $(2018,63)$. Yet, whilst joint-intention is necessary for acting together, it's not sufficient, as there must also be the kind of mutual responsiveness Cuneo describes in his account liturgical singing. Wolterstorff observes that if one person...says the creed very slowly and another says it very quickly, they are not saying the creed together' (2018, 64; emphasis in the original).

Whilst the application of the material on collective intention has its uses, it also has its short-comings. It might seem to some to suggest something too homogenous about the nature of corporate liturgical action, particularly to those from less formal liturgical traditions. As Benson notes, true worship should be recognised as a community providing 'multiple voices' $(2013,94)$. Yet, he argues, rather than thinking of liturgical communities as providing a polyphony of voices which blend together to provide 'pleasing harmony', we should instead think of liturgy as providing a heterophony of voices, which remain 'distinct and sometimes dissonant' $(2013,94)$. Liturgical worship which promotes heterophony, Benson notes, involves everyone in the community as part of the worship — whether that be lay members, pastors, priests or children. Benson's point isn't aimed at the accounts of collective action given by Cuneo or Wolterstorff, but it points to an important limitation of their accounts of collective intention in liturgy. In recent work, Joshua Cockayne (forthcoming) suggests that one limitation of collective intention accounts of group action is that they exclude neuro-atypical individuals from participating in liturgy. Cockayne points to the psychological literature on autism to make this point-many individuals with Autism Spectrum Disorder have difficulty engaging in the kind of intention meshing and mutual responsiveness described in Wolterstorff and Cuneo's accounts. This isn't to say that such accounts have no value, but just that they are limited in what they can explain. 
Cockayne then proposes a model of group action, by drawing from the work of Christian List and Philip Pettit (2011). According to List and Pettit, if a group is structured appropriately, it can meet the conditions for agency. They suggest that groups are capable of acting and responding to their environment in such a way that they can be considered responsible for acting. Cockayne suggests that such a model might help to explain how a diverse group of individuals could contribute to the worship of the church as a group, even if they are unable to jointly intend to perform acts of sung or spoken liturgy.

\section{Future directions in the philosophy of liturgy}

Much of the philosophy of liturgical action has focused on what we do when we participate in liturgy, but yet, human beings aren't the only agents acting in the liturgy of the Church. Theologically, much importance has been given to the work of the Holy Spirit in the worship of the Church. Whilst Wolterstorff has offered an account of what God is doing in the liturgy in his account of what the liturgy assumes about God's actions in The God we Worship, as well as a brief discussion of God's liturgical actions in Acting Liturgically, the work of the Holy Spirit in liturgy remains something which deserves more attention from philosophers.

A related theological issue which would undoubtedly expand the conversation in liturgical philosophy is a discussion of ecclesiology. Whilst I've highlighted some accounts of what it is for the Church to act together by using liturgy, this discussion would be improved by getting clear on the question of just what the Church is. What is the relationship between individual members of the Church, church communities, and the worldwide Church? This is surely a vital question if we are to make sense of what it is for those within the Church to engage in acting liturgically. Moreover, this is a discussion which I think philosophers could contribute a great deal to, by applying insights from work on social ontology and mereology.

In the second part of this article, I consider how liturgy might provide not just a way of acting, but also a way of knowing. I summarise the recent discussions of liturgical epistemology by explaining how liturgy can provide a way to know God personally. 


\section{Bibliography}

Benson, Bruce.

Bratman, Michael. 2009. 'Shared Agency'. in Pbilosopby of the Social Sciences. Edited by Chrysostomos Mantzavinos, (Cambridge University Press).

Caputo, John .D., $\quad$ 2007. What Would Jesus Deconstruct?(The Church and Postmodern Culture): The Good News of Postmodernism for the Church. Baker Academic.

Cockayne, Joshua. Forthcoming. 'Inclusive Worship and Group Liturgical Action'. Res Philosophica.

Cuneo, Terence. 2017. 'On the religious worth of bodily liturgical action'. Religious Studies, first view articles.

2016. Ritualized Faith. (Oxford University Press).

Gschwandtner, C.M., 2015. The Vigil as Exemplary Liturgical Experience: On Jean-Yves Lacoste's Phenomenology of Liturgy. Modern Theology, 31(4), pp.648-657.

Gschwandtner, C.M., 2013. Postmodern Apologetics?: Arguments for God in Contemporary Philosophy: Arguments for God in Contemporary Philosophy. Fordham University Press.

List, Christian

2011. Group Agency. (Oxford University Press).

\& Petit, Philip.

Price, Charles P.

\& Weil Louis.

Shilbrack, Kevin.

2014. Philosophy and the Study of Religions. (Wiley Blackwell).

Searle, John.

2010. Making the Social World. (Oxford University Press).

1990. 'Collective Intentions and Actions'. In Consciousness and Language.

(Cambridge University Press): 90-106.

Smith, James K.A. $\quad$ 2018. 'Review of Terence Cuneo, Ritualized Faith: Essays on the Philosophy of Liturgy'. Scottish Journal of Theology, Vol 71.1.

2017. Awaiting the King. (Baker Academic).

2013. Imagining the Kingdom. (Baker Academic).

2009. Desiring the Kingdom. (Baker Academic).

Wolterstorff, Nicholas. 2018. Acting Liturgically. (Oxford University Press).

2016. 'Knowing God Liturgically'. The Journal for Analytic Theology, Vol 4. 
2011. Hearing the Call. Edited by Mark R. Gornik and Gregory

Thompson. (Eerdmans).

2015. The God We Worship. (Eerdmans).

1995. Divine Discourse. (Cambridge University Press)

1990. 'Remembrance of Things (Not) Past'. In Christian Pbilosopby edited by Thomas Flint. (Notre Dame University Press): 118-61.

Wynn, Mark. 2013. Renewing the Senses: A Study of the Philosophy and Theology of the Spiritual Life. (Oxford University Press). 